Diterbitkan oleh Program Studi IImu Komunikasi

Universitas Ahmad Dahlan Yogyakarta

\title{
Pola Komunikasi Keluarga dalam Membangun Akhlakul Karimah
}

\author{
Marfuah Sri Sanityastuti, Yani Tri Wijayanti dan Alip Kunandar
}

Staf Pengajar pada Prodi Ilmu Komunikasi, UIN Sunan Kalijaga

(E-mail: sanityastuti@yahoo.com; yanitriwijayanti@gmail.com; alipyog.k@gmail.com)

\begin{abstract}
Abstrak
Keluarga adalah lingkungan sosial terkecil di dalam masyarakat dimana setiap anggotanya terikat oleh hubungan pernikahan dan darah. Dalam konteks pendidikan, keluarga adalah lingkungan utama yang pertama kalinya memberikan bekal pendidikan kepada anak dalam berbagai aspek kehidupan, terutama dalam hal pendidikan sosial-kemasyarakatan. Pendidikan dalam keluarga yang paling utama adalah dalam hal membentuk akhlak anak-anak sebagai bekal mereka dalam menghadapi kehidupannya kelak.

Setiap keluarga, khususnya keluarga muslim, kedua orangtua tentu saja berharap anak-anak mereka memiliki akhlak yang baik (akhlakul karimah). Dalam hal ini, pola komunikasi dalam keluarga memegang peranan yang sangat penting. Pola komunikasi yang baik, menggabungkan antara komunikasi verbal dan non verbal, komunikasi individu dan kelompok, ikut menentukan bagaimana akhlak seorang anak dibentuk.

Penelitian ini mencoba melihat bagaimana pola komunikasi dalam keluarga dalam mendidik anak agar memiliki akhlakul karimah pada keluarga muslim di Daerah Istimewa Yogyakarta dengan membandingkannya dengan prinsip-prinsip komunikasi dalam Al Qur'an.
\end{abstract}

Kata Kunci: Pola Komunikasi, Keluarga, Prinsip Komunikasi Al Qur'an, Akhlakul Karimah.

\section{A. Pendahuluan}

Keluarga sebagai lembaga sosial yang khas karena dalam keluarga anggotanya terdiri dari individu-individu yang mempunyai hubungan darah sangat erat, tetapi juga merupakan bagian dari masyarakat yang lebih besar. Disamping itu keluarga berkembang dalam semua lapisan masyarakat, masyarakat dapat memperoleh dukungan yang diperlukan dari anggota keluarga, sebaliknya keluarga hanya dapat bertahan kalau didukung oleh masyarakat yang lebih luas.

Kedudukan utama setiap keluarga adalah fungsi pengantara anggotanya pada masyarakat yang lebih besar, sebagai penghubung pribadi dengan struktur sosial yang lebih besar. Keluarga dapat membantu keberlangsungan masyarakat dengan mengambil beberapa tugas untuk mengantarkan anggota keluarganya memasuki tempat yang lebih besar. Sebuah masyarakat besar tidak akan bisa bertahan apabila kebutuhannya yang bermacam-macam tidak terpenuhi, misalnya regenerasi, proses produksi, pembagian makanan, perlindungan anak, persamaan hukum, pengembangan generasi muda dalam kehidupan sosial (Goode, 2007: 7).

Keberadaan keluarga dapat memotivasi anggotanya untuk mengabdikan diri pada kepentingan umum agar masyarakat dapat bertahan, karena lembaga-lembaga kemasyarakatan selain keluarga hanya sekedar mampu memaksa individu-individu yang membangkang untuk menyesuaikan diri dan tidak melakukan penyelewengan. Oleh karena itu diperlukan kekuatan sosial yang dapat mengendalikan dan mengontrol individu setiap 
saat untuk berbuat baik atau buruk, untuk mendukung kontrol intern maupun kontrol resmi dari lembaga-lembaga masyarakat.

Tugas-tugas keluarga merupakan tanggungjawab langsung setiap individu dalam masyarakat, setiap orang dilahirkan dalam keluarga, dan akan membentuk keluarganya sendiri. Setiap orang menjadi sanak keluarga dari banyak orang. Dalam kenyataan sosial banyak orang yang dapat lolos dari kewajiban agama, yang oleh orang lain dianggap sebagai sebuah keharusan, tidak semua peran dan tanggungjawab keluarga yang dapat diwakilkan kepada orang lain.

Peran setiap individu dalam keluarga merupakan sebuah keniscayaan, meskipun tidak ada dukungan hukum resmi yang mengontrol, sehingga semua individu selalu mengambil bagian. Misalnya suami harus mengambil peran ekonomi dan produktifitas agar keluarga tidak kelaparan, istri menjaga diri dan kandungannya agar individu lain dapat menjadi pengikat dalam keluarga, individu yang lebih tua akan mengambil peran pengganti orang tua dan sebagainya.

Fungsi utama keluarga dalam perkembangan masyarakat yang lebih luas adalah lebih pada kelahiran individu, pemeliharaan anak, penempatan anak dalam masyarakat, pemasyarakan dan kontrol sosial. Meskipun fungsi itu dapat dipisah-pisah dan diwakilkan pada lembaga lain, namun keberadaan keluarga menjadi faktor penting dalam penempatan anak pada masyarakat yang lebih luas (Goode, 2007: 11).

Masyarakat perkotaan mempunyai permasalahan yang lebih komplek daripada masyarakat pedesaan, sementara fungsi-fungsi keluarga pada masyarakat perkotaan justru mulai memudar dan terpisah-pisah sehubungan dengan kesibukan ayah dan ibu dalam mencari nafkah. Sehingga fungsi-fungsi keluarga banyak diwakilkan pada lembaga sosial yang lain, misalnya pemeliharaan diberikan pada baby sitter, fungsi pendidikan dan kontrol sosial merasa cukup dengan diwakilkan pada sekolah.

Ketika fungsi-fungsi keluarga mulai dipecah-pecah dan diberikan kepada lembaga lain maka peran individu-individu dalam keluarga mulai menipis. Peran anggota keluarga yang menipis membuat interaksi dan komunikasi dalam keluarga menjadi tidak intens lagi, sehingga hubungan antar anggota keluarga menjadi renggang.

Hubungan antara orang tua dan anak yang renggang akibat jarangnya berkomunikasi membuat orang tua kehilangan nilai teladan bagi anak dan anak akan mencari figur di luar keluarga sebagai tokoh idaman. Kondisi ini membuat banyak anakanak mencontoh tokoh idaman yang kadang tidak sesuai dengan harapan keluarga.

Keluarga yang sudah tidak dapat memerankan fungsinya akan banyak mengalami permasalahan, misalnya kenakalan anak (remaja) yang sudah menjurus pada kriminalitas., bahkan akhir-akhir ini terjadi pembunuhan beberapa remaja putri oleh mantan pacarnya. Semakin berkembang kejadian tawuran pelajar yang terjadi baik di kota besar maupun di kota kecil. Beberapa tahun yang lalu dikejutkan adanya kasus anak SD yang bunuh diri karena tidak bisa bayar uang iuran ketrampilan.

Kejadian-kejadian yang disebutkan diatas merupakan cermin rusaknya mentalitas dan akhlak anak-anak, dimana anak semuanya berasal dari keluaraga. Untuk itu pendidikan akhlak antar anggota keluarga merupakan sebuah keharusan. Pilar pendidikan akhlak yang paling utama adalah kebiasaan anak sejak kecil dilatih untuk melakukan ibadah sesuai dengan ajaran-ajaran Islam. Bagaimana seorang ayah atau ibu dapat mengajak anak- 
Diterbitkan oleh Program Studi IImu Komunikasi

Universitas Ahmad Dahlan Yogyakarta

anaknya untuk melakukan ibadah secara rutin, misalnya sholat lima waktu, mengaji setiap habis sholat magrib, ikut berjamaah di Masjid atau melaksanakan puasa di Bulan Ramadhan.

Membiasakan ibadah pada anak tentu tidak bisa terlepas dari bagaimana orang tua dapat membangun pola komunikasi yang tepat, agar anak merasa enjoy dalam melaksanakan ibadahnya. Komunikasi antara ayah dan ibu dapat menjadi panutan bagi anak-anaknya dalam berkomunikasi pada siapapun, komunikasi antar saudara dalam keluarga dapat memberi rasa aman dan percaya diri pada masing-masing.

Pola komunikasi keluarga dalam membiasakan anak beribadah perlu diteliti beberapa keluarga yang telah berhasil mendidik anak-anaknya, sehingga menjadi anak yang berakhlak mulia (akhlaqul kharimah). Keluarga akan menjadi tempat mencari informasi-informasi tentang komunikasi yang dilakukan antar anggota keluarga dalam membiasakan anak-anaknya beribadah sesuai syariah.

Penelitian ini menjawab rumusan masalah sebagai berikut, bagaimanakah pola komunikasi keluarga dalam membiasakan anak beribadah sebagai pilar utama akhlaqul kharimah? Tujuan dalam penelitian ini adalah ingin mengetahui pola komunikasi dalam keluarga, antara orang tua dan anak dalam membiasakan hidup islami yaitu berupa unsurunsur: (1) frekuensi, lama waktu, dan (2) bentuk komunikasi yang digunakan, (3) perangkat yang digunakan, (4) fungsi komunikasi, (5) ungkapan/ simbol/ bahasa khusus, (6) konten materi yang dipertukarkan, dan (7) urgensi komunikasi yang terjadi sebagai bagian menjaga etika prinsip komunikasi Islam seperti qawlan karima (perkataan yang manis), qawlan sadida (perkataan yang benar), qawlan ma'rufa (perkataan yang baik), qawlan baligha (perkataan yang efektif), qawlan layyina (perkataan yang lemah lembut), dan qawlan maisura (perkataan yang pantas) ketika orangtua berkomunikasi dengan anak.

Diperoleh asumsi dasar bahwa komunikasi berhubungan dengan perilaku manusia dan kepuasan terpenuhinya kebutuhan berinteraksi dengan manusia-manusia lainnya. Hampir setiap orang membutuhkan hubungan sosial dengan orang-orang lainnya dan kebutuhan ini terpenuhi melalui pertukaran pesan yang berfungsi sebagai jembatan untuk mempersatukan manusia-manusia yang tanpa berkomunikasi akan terisolasi. Pesan-pesan itu mengemuka lewat perilaku manusia. Ketika kita melambaikan tangan, tersenyum, bermuka masam, menganggukkan kepala, atau memberikan suatu isyarat, kita juga sedang berperilaku. Sering perilaku-perilaku ini merupakan pesan-pesan; pesan-pesan itu digunakan untuk mengkomunikasikan sesuatu kepada seseorang (Porter dan Samovar, dalam Mulyana dan Rakhmat, 2006:12).

Komunikasi menurut Hovland adalah proses mengubah perilaku orang lain (communication is the process to modify the behavior of the other individuals), sedangkan Harlod Laswell menyatakan bahwa cara yang baik untuk menjelaskan komunikasi adalah menjawab pertanyaan sebagai berikut: Who Says What in Which Channel to Whom With What Effect?. Paradigma Laswell ini menunjukkan bahwa komunikasi meliputi lima unsur sebagai jawaban dari pertanyaan di atas, yaitu: komunikator, pesan, media, komunikan dan efek (Effendy, 2011: 10).

Komunikasi sebagai proses, ada beberapa karakteristik lainnya yang membantu memahami bagaimana komunikasi berlangsung: Pertama, komunikasi itu dinamik. Komunikasi adalah suatu aktivitas yang terus berlangsung dan selalu berubah. Sebagai para 
pelaku komunikasi, secara konstan kita dipengaruhi oleh pesan orang lain dan sebagai konsekuensinya, kita mengalami perubahan yang terus menerus. Setiap orang kita dalam hidup sehari-hari bertemu dan berinteraksi dengan orang-orang dan orang-orang ini mempengaruhi kita. Kedua, komunikasi itu interaktif. Komunikasi terjadi antara sumber dengan penerima, ini mengimplikasikan dua orang atau lebih yang membawa latar belakang dan pengalaman unik mereka masing-masing ke peristiwa komunikasi. Ketiga, komunikasi itu tidak dapat dibalik (irreversible) dalam arti bahwa sekali kita mengatakan sesuatu dan seseorang telah menerima dan men-decode pesan, kita tidak dapat menarik kembali pesan itu dan sama sekali meniadakan pengaruhnya. Dan keempat, komunikasi berlangsung dalam konteks fisik dan konteks sosial. Lingkungan fisik meliputi objek-objek fisik tertentu seperti mebel, gorden jendela, karpet, cahaya, keheningan atau kebisingan, tumbuh-tumbuhan, ada atau tidak adanya kesemrawutan, pesan-pesan lain yang menyaingi, dan sebagainya. Konteks sosial menentukan hubungan sosial antara sumber dan penerima. Perbedaan-perbedaan posisi seperti guru-murid, atasan-bawahan, orangtua-anak, dokterpasien dan sebagainya mempengaruhi proses komunikasi (Mulyana dan Rakhmat, 2006:16-17).

Pola menyangkut pesan yang terkait dengan situasi dan kondisi yang mengacu pada 'suatu yang membungkus inti pesan itu sendiri'. Pola memberikan data untuk memahami dan mengerti tindakan atau tingkah laku seseorang, kelompok (keluarga) atau organisasi yang muncul. Pola komunikasi menunjukkan suatu identifikasi untuk mengakses tingkah laku komunikasi dalam suatu sistem karena pola komunikasi menyediakan konteks atau ruang untuk memahami tingkah laku yang spesifik. Pola komunikasi disesuaikan dengan kondisi anggota dan komunikasi yang ada saat berinteraksi dengan lingkungannya. Pola ini bila dihubungkan dengan figur komunikator, pesan, dan media akan menjadi suatu rangkaian yang beragam dan berkembang (Katz dan Kahn dalam Pace dan Faules, 2006:174-175) dalam suatu rangkaian di mana komunikasi yang terjalin mengarahkan tujuan pembinaan komunikasi keluarga.

Keluarga mewakili suatu konstelasi hubungan yang sangat khusus. Definisi hukum dari keluarga adalah sekelompok orang yang terikat oleh darah, perkawinan dan adopsi. Menurut Galvin dan Brommel (dalam Tubss dan Moss, 2008:215) mendefinisikan keluarga adalah jaringan orang-orang yang berbagi kehidupan mereka dala jangka waktu yang lama; yang terikat perkawinan, darah, atau komitmen, legal atau tidak; yang menganggap diri mereka sebagai keluarga; dan yang berbagi pengharapan-pengharapan masa depan mengenai hubungan yang berkaitan.

Keluarga dipandang sebagai sebuah sistem, menekankan hubungan-hubungan keluarga ketimbang anggota-anggota perseorangan. Pemahaman atas keluarga seperti ini, sebagai suatu keseluruhan ketimbang sebagai sejumlah anggota perseorangan, mengalihkan perhatian ke pola-pola hubungan dan siklus-siklus perilaku alih-alih sebab dan akibat. Setiap anggota mempengaruhi orang-orang lainnya tapi pada gilirannya dipengaruhi oleh mereka (Bocher dan Eisenberg dalam Tubss dan Moss, 2008:215).

Komunikasi adalah suatu kegiatan yang pasti terjadi dalam kehidupan keluarga, tanpa komunikasi, sepi kehidupan keluarga dan kegiatan berbicara, berdialog, bertukar pikiran dan sebagainya. Akibatnya kerawanan hubungan antara anggota keluarga pun sukar dihindari. Komunikasi antara suami dan istri, komunikasi antara ayah ibu dan anak, 
Diterbitkan oleh Program Studi IImu Komunikasi

Universitas Ahmad Dahlan Yogyakarta

komunikasi ayah dan anak, komunikasi ibu dan anak, dan komunikasi antara anak dan anak. Perlu dibangun secara harmonis dalam rangka membangun pendidikan yang baik dalam keluarga.

Pola atau cara seseorang berkomunikasi dengan lainnya bukanlah hal yang sederhana. Pola komunikasi keluarga menggambarkan kecenderungan suatu keluarga untuk membangun bagaimana cara yang paling sesuai untuk berkomunikasi satu sama lain di dalamnya. Pola ini bukan proses yang disengaja dan bukan tujuan akhir di antara mereka yang terlibat. Pola komunikasi sesungguhnya lebih merujuk pada modus yang muncul dari sebuah proses yang terjadi dari sebuah keluarga. Ada beberapa faktor yang dapat mempengaruhi komunikasi dalam keluarga, yaitu: (1) Citra diri dan citra orang lain, citra diri diartikan sebagai bagaimana individu memandang dirinya sendri. Seperti pendapat anak mengenai kemampuannya akan mempengaruhi pada saat bagaimana ia harus merespon dan menyaring informasi yang didapatnya dari orang tua. Sementara citra orang lain adalah bagaimana pendapat atau pandangan individu lain terhadap suatu individu; (2) Suasana psikologis, merupakan keadaan emosi individu, apakah itu senang, sedih, marah dan lain-lain, yang dapat menghambat atau mempermudah jalannya komunikasi; (3) Lingkungan fisik, keluarga merupakan lingkungan fisik yang dapat mempengaruhi gaya dan cara berkomunikasi. Setiap keluarga memiliki aturan, norma dan gaya hidup masingmasing, yang dapat berpengaruh kepada bagaimana cara mereka berkomunikasi; (4) Kepemimpinan, ada tiga tipe kepemimpinan dalam keluarga yang dapat mempengaruhi cara berkomunikasi yaitu otoriter, demokrasi dan laissez fairez; (5) Bahasa, merupakan alat untuk mengekspresikan sesuatu yang bersifat verbal, masing-masing keluarga memiliki bahasa yang berbeda bergantung kepada latar belakang budaya atau etnis; dan (6) Perbedaan usia, usia mempengaruhi komunikasi melalui pemilihan bahasa yang tepat (Devito, 1997: 301 dalam Novianti, 2013: 22-23).

Bentuk komunikasi dalam keluarga menurut Novianti (2013:24-25), antara lain, yaitu:

(1) Komunikasi verbal. Komunikasi merupakan suatu kegiatan antara individu atau kelompok yang mempergunakan bahasa sebagai alat perhubungan. Kegiatan komunikasi verbal menempati frekuensi terbanyak dalam keluarga. Setiap hari orang tua selalu ingin berbincang-bincang kepada anaknya. Dalam perhubungan antara orang tua dan anak akan terjadi interaksi; (2) Komunikasi non verbal. Komunikasi non verbal suatu ketika bisa berfungsi sebagai penguat komunikasi verbal. Komunikasi non verbal terasa jika secara verbal tidak mampu mengungkapkan sesuatu secara jelas. Mark L. Knapp, menyebutkan ada lima macam fungsi pesan non verbal, yaitu : (a) Repetisi, mengulang kembali gagasan yang sudah disajikan secara verbal; (b) Subtitusi, mengantikan lambang-lambang verbal; (c) Kontradiksi, menolak pesan verbal atau memberikan makna yang lain terhadap pesan verbal; (d) Komplemen, melengkapi dan memperkaya makna pesan nonverbal; (e) Aksentuasi, menegaskan pesan verbal atau menggarisbawahinya (Djamarah, 2004:44); (3) Komunikasi individual. Komunikasi individual atau komunikasi interpersonal adalah komunikasi yang sering terjadi dalam keluarga. Komunikasi yang terjadi berlangsung dalam sebuah interaksi antarpribadi; antara suami dan istri, antara ayah dan anak, antara ibu dan anak, dan antar anak dan anak; dan (4) Komunikasi kelompok, hubungan akrab antara orang tua dan anak sangat 
penting untuk dibina dalam keluarga. Sebenarnya, pertemuan anggota keluarga untuk duduk bersama dalam satu waktu dan kesempatan, sangat penting sebagai simbol keakraban keluarga.

Kaitannya dengan Etika Komunikasi dalam Islam terutama ketika terjadi komunikasi dalam keluarga atau komunikasi antara orangtua dan anak, di mana seperti qawlan karima (perkataan yang manis), qawlan sadida (perkataan yang benar), qawlan ma'rufa (perkataan yang baik), qawlan baligha (perkataan yang efektif), qawlan layyina (perkataan yang lemah lembut), dan qawlan maisura (perkataan yang pantas). Seperti halnya prinsip-prinsip Komunikasi dalam Al-Quran seperti yang dikemukan oleh Fajar Waryani Riyanto (2011:155), antara lain sebagai berikut ini:

\section{Prinsip Qaulan Baliga (Komunikasi Akuratif)}

Bahwa perkataan tersebut mengandung tiga unsur utama, yaitu bahasanya tepat, sesuai dengan yang dikehendaki, dan isi perkataan adalah suatu kebenaran. Sedangkan kata balig dalam konteks pembicara dan lawan bicara, adalah bahwa si pembicara secara sengaja hendak menyampaikan sesuatu dengan cara yang benar agar bisa diterima oleh pihak yang diajak bicara.

a. Prinsip Qaulan Karima (Komunikasi Etikatif)

Term karim dirangkai dengan kata qaul atau perkataan, maka berarti suatu perkataan yang menjadikan pihak lain tetap dalam kemuliaan, atau perkataan yang membawa manfaat bagi pihak lain, tanpa bermaksud merendahkannya. Sayyid Qutb, sebagaimana dikutip oleh Quraish Shihab misalnya menyatakan, bahwa perkataan yang karim, dalam konteks hubungan dengan kedua orang tua, pada hakikatnya adalah tingkatan tertinggi yang harus dilakukan oleh seorang anak. Yakni, bagaimana ia berkata kepadanya, namun keduanya tetap merasa dimuliakan dan dihormati. Ibn 'Asyur menyatakan, bahwa qaul karim adalah perkataan yang tidak memojokkan pihak lain yang membuat dirinya merasa seakan terhina.

b. Prinsip Qaulan Maisura (Komunikasi Reflektif)

Pada prinsipnya, qaul maisuran adalah segala bentuk perkataan yang baik, lembut, dan melegakan. Ada juga yang menjelaskan, qaul maisura adalah menjawab dengan cara yang sangat baik, perkataan yang lembut dan tidak mengada-ada.

\section{Prinsip Qaulan Ma'ruf (Komunikasi Adaptif)}

Qaul ma'ruf adalah perkataan yang baik, yang menancap ke dalam jiwa, sehingga yang diajak bicara tidak merasa dianggap bodoh (safih); perkataan yang mengandung penyesalan ketika tidak bisa memberi atau membantu; Perkataan yang tidak menyakitkan dan yang sudah dikenal sebagai perkataan yang baik.

a. Prinsip Qaulan Layyina (Komunikasi Fleksibelistik)

Qaul layyina adalah perkataan yang mengandung anjuran, ajakan, pemberian contoh, di mana si pembicara berusaha meyakinkan pihak lain bahwa apa yang disampaikan adalah benar dan rasional, dengan tidak bermaksud merendahkan pendapat atau pandangan orang yang diajak bicara tersebut. 
Diterbitkan oleh Program Studi IImu Komunikasi Universitas Ahmad Dahlan Yogyakarta

b. Prinsip Qaulan Sadida (Komunikasi Solutif)

Qaul sadid menduduki posisi yang cukup penting dalam konteks kualitas keimanan dan ketaqwaan seseorang. Sementara berkaitan dengan qaul sadid, terdapat banyak penafsiran, antara lain, perkataan yang jujur dan tepat sasaran, perkataan yang lembut dan mengandung pemuliaan bagi pihak lain, pembicaraan yang tepat sasaran dan logis, perkataan yang tidak menyakitkan pihak lain, perkataan yang memiliki kesesuaian antara yang diucapkan dengan apa yang ada di dalam hatinya

Penelitian ini menggunakan metode kualitatif studi etnografi, karena metode ini dapat menggambarkan, menjelaskan dan membangun hubungan dari kategori-kategori dan data yang ditemukan untuk dapat menjelaskan perilaku dari suatu kelompok masyarakat. Penelitian ini menghasilkan data deskriptif berupa kata tertulis dari orang atau perilaku yang diamati dengan etnografi, yang merupakan salah satu strategi penelitian kualitatif yang di dalamnya peneliti menyelidiki suatu kelompok kebudayaan di lingkungan yang alamiah dalam periode yang cukup lama dalam pengumpulan data utama, data observasi dan data wawancara (Cresswell, 2010:20). Proses penelitiannya fleksibel dan biasanya berkembang sesuai kondisi dalam merespon kenyataan-kenyataan hidup yang dijumpai di lapangan. Tujuan penelitian kualitatif adalah memahami situasi, peristiwa, kelompok, atau interaksi sosial tertentu. Penelitian ini dapat diartikan sebagai proses investigatif yang di dalamnya peneliti secara perlahan-lahan memaknai suatu fenomena sosial dengan membedakan, membandingkan, menggandakan, mengatalogkan, dan mengklasifikasikan objek penelitian. Peneliti memasuki dunia informan melalui interaksi berkelanjutan, mencari makna-makna dan perspektif informan.

Urutan penelitian sebagai berikut yaitu mengumpulkan data yang dibutuhkan dalam kegiatan penelitian ini dengan mengambil sampel bertujuan (purposive sampling), karena pemilihan satu kasus atau satu individu lazimnya didasari pertimbangan bahwa kasus atau individu tersebut dianggap khas (typical) sebagai subjek penelitian (Kuswarno, 2008:62). Penelitian etnografi ini akses pengumpulan data diperoleh dari seseorang atau gatekeeper yang menjadi anggota kelompok masyarakat yang diteliti, gatekeeper ini juga yang nanti menghubungkan peneliti dengan responden penelitian. Selanjutnya responden merupakan sumber data yang utama bagi penelitian etnografi ini, selain hasil pengamatan. Dari informan ini diperoleh model asli pola komunikasi dalam keluarga yang akan diteliti.

Kriteria responden yang dibutuhkan adalah informan yang hidup dalam lingkungan keluarga inti yang yang beragama Islam. Kriteria: (1) Sampel tinggal di Provinsi Daerah Istimewa Yogyakarta, yang terdiri dari 1 kotamadya yaitu Kota Yogyakarta, dan 4 kabupaten yaitu Kabupaten Sleman, Kabupaten Bantul, Kabupaten Kulon Progo dan Kabupaten Bantul; (2) Keluarga Muslim, terdiri dari orang tua dan anak (4) bersedia diwawancarai/ diteliti.

\section{B. Pembahasan}

Dalam sebuah keluarga, komunikasi verbal dianggap sebagai bentuk komunikasi yang paling dominan. Keluarga dari pasangan Zainal (53) dan Dian (49) dari Sleman 
misalnya, menempatkan komunikasi verbal sebagai cara paling utama dalam membentuk akhlaqul karimah dalam keluarganya. Pasangan yang telah dikaruniai dua orang putra berusia 21 dan 17 tahun ini sealalu mengajak anak-anaknya untuk melakukan ibadah dengan komunikasi lisan, yakni dengan mengajak langsung, misalnya pada waktu shalat tiba, jika anak-anaknya berada di rumah akan langsung diajak shalat berjamaah, sementara jika anaknya sedang berada di luar, kadang mereka mengingatkannya melalui pesan singkat (SMS) atau dengan menasihatinya sebelumnya, agar anak-anak mereka tidak meninggalkan shalat.

Komunikasi verbal ini juga diperkuat dengan komunikasi non verbal, dalam hal ini dengan memberi contoh langsung. Contoh langsung ini, misalnya dalam hal menanamkan kebiasaan dalam bersadaqah. "Saat di masjid, saya meminta anak saya memasukkan uang ke dalam kotak infak. Saat anak-anak masih kecil mereka bertanya dan saya menjelaskan kegunaan infak dan sadaqah, dan setelah mereka besar, mereka terbiasa untuk menyisihkan uang sakunya untuk infaq, misalnya saja saat melaksanakan shalat jum'at," papar Dian.

Memberi contoh langsung juga dianggap sebagai bentuk komunikasi yang efektif bagi keluarga pasangan Sasongko (55) dan Udkhiyah (50) dari Kayunan, Sleman. Misalnya saja dalam hal ibadah shalat, keluarga yang dikaruniai tiga orang putri berusia 25,19 , dan 15 tahun ini, "Kita ajak anak-anak untuk shalat bareng sejak kecil, mungkin waktu itu hanya ikut-ikutan saja, doa dan pemahamannya belakangan, yang penting mereka terbiasa dulu," ungkap Udkhiyah.

Komunikasi verbal dilakukan keluarga ini untuk menjaga anak-anaknya agar tidak melakukan hal-hal yang tidak baik di luar, "Saya selalu mengatakan kepada anak-anak kalau orang tua itu adalah sahabatnya, jadi jangan takut jika mau cerita, soal teman, sekolah, kerja, hobinya, bahkan hingga urusan teman lelaki. Alhamdulillah mereka sudah terbiasa terbuka," tambah Udhkiyah.

Penggabungan antara ajakan dan memberi contoh langsung ini sejalan dengan prinsip qaulan baliga, karena apa yang dikatakan orang tua akan terlihat sebagai sebuah kebenaran oleh anak-anak, jika orangtuanya juga melakukan apa yang dikatakannya. Dengan mengajak dan memberi contoh, anak-anak sebagai penerima pesan akan mudah menerima pesan itu.

Anak-anak melakukan kesalahan adalah hal yang biasa dalam keluarga. Bagi keluarga Iyarti di Kulonprogo, hal yang paling penting adalah memberitahukan kepada anak-anak bahwa sikap atau perilaku mereka itu salah, tetapi dengan cara yang lembut, "Waktu mereka masih kecil, kita akan nasihatin, tidak dimarahi. Tapi kalau sudah besar, dan masih melakukannya, ya sekali-kali dimarahi agar mereka kembali ingat kalau itu adalah hal yang salah," kata Iyarti. Hal itu senada dengan keluarga Atifah di Kulonprogo, "Saya termasuk rewel sama anak-anak, misalnya mau pergi ke mana saya tanya terus. Hal itu untuk kebaikan mereka sendiri," kata Atifah.

Apa yang dilakukan oleh keluarga Iyarti dan Atifah adalah bentuk dari prinsip qaulan karima, yakni memperingatkan untuk mengarahkan pada sesuatu yang bermanfaat, tetapi tidak merendahkan. Menasihati anak jika melakukan kesalahan dan rewel dalam mengontrol kegiatan anak-anak pada dasarnya adalah untuk kebaikan anak-anak sendiri, bukan untuk memberikan hukuman atau merendahkan mereka. 
Diterbitkan oleh Program Studi IImu Komunikasi

Universitas Ahmad Dahlan Yogyakarta

Keluarga Slamet (65) dan Mahfiah (62) dari Ndagen Yogyakarta yang memiliki anak yang sudah berkeluarga, masih berusaha untuk berkomunikasi dengan anak-anaknya. Kadang, anak-anak mereka bercerita tentang masalah anak-anaknya (cucu). Di sini, Slamet dan Mahfiah kadang memberikan nasihat kepada anak-anaknya agar bersabar dalam menghadapi masalah anak-anak (cucu) dengan memberi contoh, jika mereka (analanaknya) pernah melakukan kesalahan yang sama di masa kecil. Ini dilakukan untuk memberikan semacam refleksi, bahwa kesalahan yang dilakukan anak-anak adalah hal yang biasa, yang penting orang tuanya bisa mengingatkan mereka dan memberi contoh yang baik. Hal ini sejalan dengan prinsip qaulan maisura, yakni memberikan perasaan lega dan lembut bagi komunikan yang diajak bicara, dalam hal ini anak-anak mereka yang sudah menjadi orang tua.

Keluarga Ananda di Bantul yang memiliki dua anak berusia 10 dan 2,5 tahun berusaha menjaga lisan mereka agar tidak mengeluarkan kata-kata yang tidak baik yang bisa didengar dan ditiru oleh anak-anaknya, apalagi anak-anaknya masih kecil. Jika anaknya melakukan kesalahan, Ananda berusaha untuk tidak memarahi mereka, apalagi dengan kata-kata yang kasar. Hal ini sejalan dengan prinsip qaulan ma'ruf, yakni menjaga perkataan yang tidak membuat penerima pesan merasa dianggap bodoh atau sakit hati.

Prinsip qaulan layyina diterapkan dalam komunikasi dalam keluarga pasangan Giyono (45) dan Sumar (40) dari Panggang, Gunungkidul, misalnya saja dalam hal bersadaqah. Giyono menjelaskan kepada anak-anaknya dengan mengatakan:

"Kalo sodaqoh mungkin harta kecil-kecilan. Tapi yg penting ilmu dan tenaga. Kalo berupa materi belum cukup, jadi sodaqoh berupa ilmu dan tenaga. Kalo baru pulang dari pondok anak-anak yg kecil diajak, diberi pengetahuan, dan tenaga itu harus, kalo ada gotong royong, kalo ada kesulitan apa itu sebisa mungkin membantu. Mungkin kalo uang belum bisa, karena dia belum berpenghasilan. Mungkin sekedar jatah uang saku, kalo ada temannya kekurangan dibagi meskipun sam-sama sedikit."

Prinsip ini juga diterapkan dalam keluarga Agusdi (53) dan Rujini (48) dari Gunungkidul, bahwa segala sesuatu yang diajarkan dalam agama sebetulnya memiliki penjelasan atau rasionalisasinya. Misalnya dalam hal puasa.

"Anak saya pertama kali belajar puasa waktu kelas 2 SD, pertama kali puasa setengah hari baru mulai belajar untuk puasa full sehari. Biasanya buka puasa kita juga bareng sekeluarga, sahur juga. Tapi biasanya anak susah kalo untuk bangun makan sahur. Mereka belajar puasa dari kita orang tua, di sekolah juga diajarkan sama guru agama mereka manfaat puasa, kewajiban beribadah apa aja."

Sementara, prinsip qaulan sadida atau perkataan yang berkaitan dengan kejujuran, diterapkan dalam keluarga Anita Heltiana (47) dari Wirobrajan Yogyakarta. Anita mengajari anak-anaknya untuk menyampaikan perasaannya tanpa ditutup-tutupi, atau bersikap jujur. 
"Jadi anak saya itu, biar marah sama ibunya tidak sampai keluar kata yang kasar. Kalau nggak suka, anak saya bilang 'aku ngga suka ibu kayak gitu' gitu aja."

Dari kesepuluh keluarga yang dijadikan informan dalam penelitian ini, komunikasi verbal seperti ajakan pada kebaikan dan larangan pada keburukan, digabungkan dengan komunikasi non verbal seperti dengan cara memberi contoh pada sebuah tindakan yang baik. Pola komunikasi individual diterapkan dalam hal-hal yang sifatnya tidak direncanakan, sementara komunikasi kelompok dilakukan dalam situasi-situasi tertentu ketika keluarga berkumpul untuk kegiatan rutin seperti makan malam, atau ketika ada masalah yang harus dibicarakan di dalam keluarga.

\section{Kesimpulan}

Prinsip-prinsip komunikasi dalam Alqur'an seperti qaulan baliga, qaulan karima, qaulan maisura, qaulan ma 'tuf, qaulan layyina, dan qaulan sadida sudah diterapkan dalam keluarga-keluarga yang dijadikan informan dalam penelitian ini dengan pola komunikasi gabungan antara verbal-non verbal dan individu-kelompok. Akan tetapi, dalam aplikasinya setiap keluarga memiliki kekhasan masing-masing sesuai dengan situasi, latar belakang budaya, tingkat pemahaman keagamaan, dan sebagainya.

Pada akhirnya, harapan akan perilaku anak yang memiliki sifat akhlakul karimah, akan ditentukan oleh anak-anak itu sendiri. Akan tetapi, keluarga, sebagai lingkungan pertama si anak memiliki peran yang sangat penting dalam membentuknya. Dalam proses pembentukan ini, pola komunikasi yang digunakan dalam keluarga memegang peranan yang sangat penting.

\section{Daftar Pustaka}

Creswell, John W. 2010. Research Design: Pendekatan Kualitatif, Kuantitatif, dan Mixed. Yogyakarta: Pustaka Pelajar

Djamarah, Syaiful Bahri. 2004. Pola Komunikasi Orang Tua dan Anak dalam Keluarga. Sebuah Prespektif Pendidikan Islam. Bandung: Rineka Cipta

Kuswarno, Engkus (2008). Etnografi Komunikasi. Bandung: Widya Padjadjaran

Novianti, Evi. 2013. Pola Komunikasi Keluarga Antar Budaya. Bandung: Arsad Press

Pace, R. Wayne \& Don F. Faules. 2006. Komunikasi Organisasi. Strategi Meningkatkan Kinerja Perusahaan. Bandung: Remaja Rosdakarya

Porter, Richard E. dan Larry A. Samovar, dalam Deddy Mulyana dan Jalaluddin Rakhmat. 2006. Komunikasi Antarbudaya. Panduan Berkomunikasi dengan Orang-orang Berbeda Budaya, Bandung: Remaja Rosdakarya

Riyanto, Waryani Fajar. 2011. Sistem Etika Verbalistik. Metakomunikasi Islam. Perspektif Tafsir "Tematik" al-Qur'an, Yogyakarta: Mahameru Press

Tubss, Stewart L dan Syvia Moss, Pengantar Deddy Mulyana. 2008. Human Communication. Prinsip-prinsip Dasar Buku Pertama. Bandung: Remaja Rosdakarya. 